\title{
Changes in Chemo-Enzymatic properties of Soil under Different Drip Irrigation and Fertigation Levels with Cow Urine and Biofertilizers in Protected Condition
}

\author{
Sunil Kumar*, Naveen Datt, Manpreet Singh and Ibajanai Kurbah
}

Dept. of Soil Science, CSK Himachal Pradesh Agricultural University, Palampur (176 062), India

\section{Corresponding Author}

Sunil Kumar

e-mail: dukegarhwal@gmail.com
Article History

Article ID: 3 C0263

Received in $26^{\text {th }}$ September, 2017

Received in revised form $27^{\text {th }}$ November, 2017

Accepted in final form $4^{\text {th }}$ December, 2017

\begin{abstract}
The effect of different levels of fertigation and drip irrigation was studied along with applications of cow urine and biofertilizers on chemo enzymatic and biological properties of soil during summer season in a naturally ventilated poly house. The experiment was laid out in

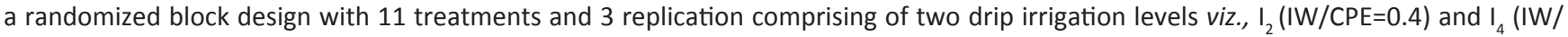
$\mathrm{CPE}=0.8)$, five fertigation levels, one farmers' practice and applications of cow urine and biofertilizers. The ammonical $\left(\mathrm{NH}_{4}\right)$ and nitrate $\left(\mathrm{NO}_{3}\right.$ ) forms of soil nitrogen content in treatments $\mathrm{F}_{2} \mathrm{I}_{4}$ and $\mathrm{F}_{2} \mathrm{I}_{2}$ (where $\mathrm{F}_{2}$ is $100 \%$ of recommended NPK doses $\left(1 / 3^{\text {rd }} \mathrm{N}\right.$ and full $\mathrm{P}, \mathrm{K}$ applied as basal and $2 / 3^{\text {rd }} \mathrm{N}$ through fertigation+Azotobacter+PSB) and $5 \%$ cow-urine) were significantly superior then farmers' practice ( $\left.T_{11}\right)$ at both depths (0.0-0.15 $\mathrm{m}$ and $0.15-0.30 \mathrm{~m})$. Similarly, trends followed by the biomass carbon, urease and phosphatase activity at both depths. The urease activity was higher in treatments with application of cow urine than without cow urine. The overall results indicated that combined application of bio-fertilizers and fertilizers along with cow urine has positive effect on biomass carbon and chemo- enzymatic properties of soil due to enhanced of soil physical and microbiological properties and addition of nutrients in soil with saving of at least $50 \%$ of water and hence can be exploited as a sustainable approach under integrated nutrient management.
\end{abstract}

Keywords: Cucumber, nitrogen fraction, microbial biomass carbon, cow urine

\section{Introduction}

Cucumber (Cucumis sativus L.) is belonging to native of India. This is commonly grown throughout the year in all parts of the country, mainly for its immature fruits. It is a good source of vitamins B with a low calorie diet. It contains $95 \%$ of water content whichmaking it a diuretic vegetable crop, which keeps the body hydrated and helps in cleansing of body toxins. Parthenocarpic fruits are common cucumber hybrids that can be grown in off season under protected conditions due to their ability to set fruit without pollination or fertilization even at low temperatures (Monisha et al., 2014) making efficient utilization of the land, water, nutrient and other resources. Protected cultivation, also known as 'Controlled Environment Agriculture (CEA)' is highly productive, environment protective and water and land conservative cultivation practice (Jensen, 2002). The India has largest irrigation network in the world but the irrigation efficiency in India is not more than $40 \%$ (Imamsaheb et al., 2014), hence more efficient irrigation methods are required for increase irrigation efficiency above that level.The optimum soil moisture content for adequate cucumber growth and fruiting is $80-85 \%$ of field capacity. Its high requirements of soil water can be attributed to its bulky and vigorous above-ground portion which evaporates large quantity of water and its poorly developed root system characterized by low absorbing capacity and heavy leaching losses of fertilizers. Drip irrigation system is one of the advanced methods of irrigation, in which water is applied drop by drop on continuous basis through closed network of plastic pipes at frequent intervals near to the root zone for consumptive use of the crop and maintains optimum soil moisture content. It minimizes conventional losses of water by deep percolation, evaporation and run off. It can save water up to $40-70 \%$ as well as increase the crop production to the extent of 20-100\% (Reddy and Reddy, 2003).

India is the third largest producer and consumer of fertilizer in the world after that the nutrient consumption per hectare and fertilizer use efficiency is very low (Sathya et al., 2008) because the main reasons for low efficiency are the types of fertilizers used and the methods of application adopted by Indian farmers and ultimately losses of nutrients. So the use of both the inorganic and organic type of fertilizers in a balanced proportion and application through fertigation not only optimizes the water use but also increases the nutrient use efficiency. The fertigation method gives higher nutrient 
use efficiency (90\%) then the conventional methods (40-60\%) by Solaimalai et al. (2005).

Under these conditions, bio-fertilizers have emerged as potential nutrient suppliers or mobilizers in various horticultural crops to meet the day by day increasing requirements of the growing population. Incorporation of microbial inoculants not only reduces the requirement of inorganic fertilizers but also has other added advantage such as consistent and slow release of nutrients, maintaining ideal C: $\mathrm{N}$ ratio, improvement in water holding capacity and microbial biomass of soil profile, without having any adverse residual effects. The phosphorus is second most essential element for plant growth and development after nitrogen. It is sparingly soluble so major proportions of soil-P remains interlocked in insoluble forms and not available for plant uptake in the soil.

To correct the P-deficiency, indiscriminate use of P-fertilizers this deteriorates the soil quality as well as causes harmful impact on both environment and economy. Consequently, to sustain the detritus effects of chemical fertilizer on soil by the use of phosphorus solubilizing bacteria (PSBs) as an inoculant simultaneously enhances $P$ availability to plants and crop yield. The phosphorus subilizing bacteria (PSB) constitute $1-50 \%$ and fungi $0.5-0.1 \%$ of the total population in soil, Respectively (Chen et al., 2006). The use of such PSB(s) enhances plant productivity and reducing the higher use of chemical $P$ and protecting the soil environment and ecosystem from the hazards of agro chemicals. Microorganisms, especially phosphate solublizing bacteria (PSB) use as inoculants simultaneously increases $P$ uptake and therefore can be used as bio fertilizer (Nico et al., 2012).

The cow urine contains $95 \%$ water, $2.5 \%$ urea, minerals, hormones, salts, enzymes and an aqueous solution of nitrogenous and sulphurous compounds (Church, 1976) can be used as bio-fertilizers for increasing soil fertility. About $20-30 \%$ of the total $\mathrm{N}$ in the cow urine is in forms other than urea were allantoin, hippuric acid, creatinine and creatine, uric acid, xanthin, hypoxanthine and a number of amino acids were also present. As the decomposition of these compounds very slowly in soil than urea so nitrogen losses will be less through cow urine. Soil microorganisms are an important and intrinsic part of the agro ecosystem and are responsible for transforming cycles of nutrients by the urine. Cow urine has low in concentrations of carbon (C) (Lovell and Jarvis, 1996).

One gram soil contains around one billion individual microorganisms and up to 4000 species of microorganisms (Torsvik et al., 1990; Torsvik and Ovreas, 2002) in which bacteria, fungi, protozoa and algae constitute about $90 \%$ of the total soil biomass (Liesack et al., 1997). The cow urine contains urea which hydrolyzed by the urease enzyme to produce $\mathrm{NH}^{+}-\mathrm{N}$. The cow urine application often causes an increase in the microbial biomass and enzyme activity. The use of cow urine also stimulates substrate use and alters the bacterial community decreases microbial stress. The concentrations of $\mathrm{NH}^{+}-\mathrm{N}$ and $\mathrm{NO}^{-}-\mathrm{Nis}$ higher due to high soil moisture content which stimulates $\mathrm{N}$ transformations. The cow urine application as different concentration can increase the enzymatic activity and alleviate micro nutrient deficiency in the soil.

However, an effect of incorporation of cow urine and biofertilizers in fertigation scheduling has not been studied so far. Hence the objective of present paper is to study the effects of cow urine and bio-fertilizers based fertigation schedule at varying levels of drip irrigation on chemo enzymatic and biological properties of soil under protected condition.

\section{Materials and Methods}

The present study was conducted at experimental farm of CSK HPKV, Palampur $\left(32^{\circ} 6^{\circ} \mathrm{N}\right.$ latitude and $76^{\circ} 3^{\circ} \mathrm{E}$ longitude) situated at an elevation of $1290 \mathrm{~m}$ above mean sea level in Kangra district of Himachal Pradesh and represents the mid hills sub humid agro climatic zone of Himachal Pradesh in North Western Himalayas, during summer 2015 in naturally ventilated polyhouse. The cucumber cv. Hilton was transplanted on March 21, 2015. Raised strips were laid out as per plan before transplanting and were made with dimensions of $3.0 \mathrm{~m}$ length and $0.4 \mathrm{~m}$ width. The soil was clay loam and rich in clay content with accumulation of sesquioxide, $\mathrm{pH} 5.50$ and 5.75 , bulk density 1.25 and $1.30 \mathrm{Mg} \mathrm{m}^{-3}$ at $0.0-0.15 \mathrm{~m}$ and $0.15-0.30 \mathrm{~m}$ depth, respectively. The mean air temperature varies from $2{ }^{\circ} \mathrm{C}$ in January to around $36^{\circ} \mathrm{C}$ during the months of May-June. Soil temperature drops as low as $2^{\circ} \mathrm{C}$ and frost incidences are common. The relative humidity varies from 46 to $84 \%$ and average annual rainfall of the place is about $2500 \mathrm{~mm}$.

The drip irrigation system was installed in a naturally ventilated polyhouse of $15 \times 7 \mathrm{~m}^{2}$ size. A total of 33 raised strips each of $3 \times 0.4 \mathrm{~m}^{2}$ size were prepared. The average discharge rate from each dripper was 3 it $h^{-1}$. A fertigation tank system of 30 litre capacity was provided near the electric pumping unit for fertigation. The FYM @ $1 \mathrm{~kg} \mathrm{~m}^{-2}$ was applied to all the treatments. In conventional method, urea, single super phosphate and muriate of potash were used whereas, in fertigation treatments, water soluble fertilizers such as 19:19:19, 0:0:50, 12:61:0 and urea were applied through drip irrigation system. The experiment was laid out in completely randomized design with three replications of two irrigation and fertigation treatment combinations. The irrigation and fertigation treatments consisted of two irrigation levels $\left(\mathrm{I}_{2}\right.$ and $\mathrm{I}_{4}$ designated as $2 \mathrm{It} \mathrm{m}^{-2}$ and $4 \mathrm{lt} \mathrm{m}^{-2}$ daily, respectively) and five fertigation levels; $\left(F_{1}\right) 50 \%$ of recommended NPK doses $1 / 3^{\text {rd }} \mathrm{N}$ and full $\mathrm{P}, \mathrm{K}$ applied as basal and $2 / 3^{\text {rd }} \mathrm{N}$ through fertigation+Azotobacter (Azo)+PSB and 5\% cow-urine, $\left(F_{2}\right)$ $100 \%$ of recommended NPK doses $1 / 3^{\text {rd }} \mathrm{N}$ and full $\mathrm{P}, \mathrm{K}$ applied as basal and $2 / 3^{\text {rd }} \mathrm{N}$ through fertigation+ Azotobacter (Azo)+ PSB and $5 \%$ cow-urine, $\left(\mathrm{F}_{3}\right) 50 \%$ of recommended NPK doses 
$1 / 4^{\text {th }} \mathrm{N}, \mathrm{P}$ and $\mathrm{K}$ applied as basal and $3 / 4^{\text {th }} \mathrm{NPK}$ through fertigation+Azotobacter (Azo)+PSB and 5\%cow-urine, $\left(\mathrm{F}_{4}\right)$ $100 \%$ of recommended NPK doses $1 / 4^{\text {th }} N$, P and $K$ applied as basal and $3 / 4^{\text {th }}$ NPK through fertigation+Azotobacter (Azo)+ PSB and $5 \%$ cow-urine, $\left(F_{5}\right) 100 \%$ of recommended NPK doses of fertilizer applied through water soluble fertilizers (RDF= 100:50:60) and Farmers' practice (FYM @ $1 \mathrm{~kg} \mathrm{~m}^{-2}+10 \mathrm{~g} \mathrm{~m}^{-2}$

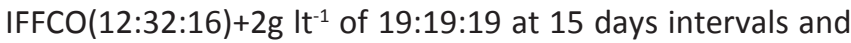
drip irrigation applied at rates $2 \mathrm{lt} \mathrm{m}^{-2}$ daily).There were 11 treatment combinations. The treatment combinations were as follows:

$T_{1-}, F_{1} I_{2}, T_{2-} F_{1} I_{4}, T_{3-}, F_{2} I_{2}, T_{4}, F_{2} I_{4}, T_{5-} F_{3} I_{2}, T_{6-}, F_{3} I_{4}, T_{7-}, F_{4} I_{2}, T_{8-} F_{4} I_{4}$ $T_{9 .} F_{5} I_{2}, T_{10}-F_{5} I_{4}, T_{11}$. Farmers' Practice.

Table 1: Analysis of soil samples for different parameter by different methods

\begin{tabular}{|c|c|c|}
\hline Parameter & Method & Reference \\
\hline Texture & $\begin{array}{l}\text { International pipette } \\
\text { method }\end{array}$ & Piper (1950) \\
\hline Bulk density & Core sampler & Singh (1980) \\
\hline Soil pH (1:2.5) & $\begin{array}{l}\text { Glass electrode } \mathrm{pH} \\
\text { meter }\end{array}$ & Jackson (1973) \\
\hline $\begin{array}{l}\text { Inorganic nitro- } \\
\text { gen fraction }\end{array}$ & $\begin{array}{l}\text { Steam distillation } \\
\text { method }\end{array}$ & Black (1965) \\
\hline $\begin{array}{l}\text { Microbial bio- } \\
\text { mass carbon }\end{array}$ & $\begin{array}{l}\text { Chloroform fumiga- } \\
\text { tion extraction }\end{array}$ & Vance et al. (1987) \\
\hline $\begin{array}{l}\text { Phosphatase } \\
\text { activity }\end{array}$ & $\begin{array}{l}\text { Colorimetric meth- } \\
\text { od }\end{array}$ & $\begin{array}{l}\text { Tabatabai and } \\
\text { Bremner (1969) }\end{array}$ \\
\hline Urease activity & $\begin{array}{l}\text { Colorimetric meth- } \\
\text { od }\end{array}$ & $\begin{array}{l}\text { Tabatabai and } \\
\text { Bremner (1972) }\end{array}$ \\
\hline
\end{tabular}

The inorganic fractions of $\mathrm{N}$ aliquot were prepared. For preparation of hydrolysate, $3 \mathrm{~g}$ of soil was shaken with $30 \mathrm{ml}$ of $2 \mathrm{~N} \mathrm{KCl}$ for $1 \mathrm{hr}$ and filtered. Then the extract was stored in refrigerator and was further used for extraction of inorganic fractions viz., $\mathrm{NH}_{4}-\mathrm{N}$ and $\mathrm{NO}_{3}-\mathrm{N}$ as per the method given by Black (1965). Soil microbial biomass carbon (SMB-C) was determined by Fumigation-extraction method as per the procedure given by Vance et al. (1987). The ureases and phosphatases activity was determined by colorimetric method (Tabatabai and Bremner, 1972).

\section{Result and Discussion}

\subsection{Inorganic fractions of nitrogen}

Inorganic fractions of nitrogen comprised ammonical $\left(\mathrm{NH}_{4}\right)$ and nitrate $\left(\mathrm{NO}_{3}\right)$ forms of $\mathrm{N}$ and are discussed below:

\subsection{1. $\mathrm{NH}_{4}-\mathrm{N}$}

Application of chemical fertilizers alone or in conjunction with FYM increased the $\mathrm{NH}_{4}-\mathrm{N}$ content of soil significantly over farmers' practice (Table 2). It varied from 26.8 and
Table 2: Effect of drip irrigation and fertigation with cow urine and biofertilizers on soil ammonicaland nitrate nitrogen status at harvest $\left(\mathrm{mg} \mathrm{kg}^{-1}\right)$

\begin{tabular}{|c|c|c|c|c|c|}
\hline \multirow{2}{*}{$\begin{array}{l}\text { Treat- } \\
\text { ments }\end{array}$} & \multirow{2}{*}{$\begin{array}{l}\text { Irrigation } \\
\text { level }\end{array}$} & \multicolumn{2}{|c|}{$\mathrm{NH}_{4}-\mathrm{N}\left(\mathrm{mg} \mathrm{kg}^{-1}\right)$} & \multicolumn{2}{|c|}{$\mathrm{NO}_{3}-\mathrm{N}\left(\mathrm{mg} \mathrm{kg}^{-1}\right)$} \\
\hline & & $\begin{array}{c}0.0- \\
0.15 \mathrm{~m}\end{array}$ & $\begin{array}{c}0.15- \\
0.30 \mathrm{~m}\end{array}$ & $\begin{array}{c}0.0- \\
0.15 \mathrm{~m}\end{array}$ & $\begin{array}{c}0.15- \\
0.30 \mathrm{~m}\end{array}$ \\
\hline$T_{1}$ & $\begin{array}{l}\mathrm{F}_{1} \mathrm{I}_{2}\left(21 \mathrm{~m}^{-2}\right. \\
\text { daily })\end{array}$ & 29.0 & 26.6 & 24.1 & 20.3 \\
\hline $\mathrm{T}_{2}$ & $\begin{array}{l}\mathrm{F}_{1} \mathrm{I}_{4}(4 \mathrm{It} \\
\mathrm{m}-2 \text { daily) }\end{array}$ & 31.6 & 28.4 & 26.1 & 22.1 \\
\hline $\mathrm{T}_{3}$ & $\begin{array}{l}\mathrm{F}_{2} \mathrm{I}_{2}\left(2 \mid \mathrm{m}^{-2}\right. \\
\text { daily })\end{array}$ & 36.8 & 35.7 & 31.6 & 30.3 \\
\hline $\mathrm{T}_{4}$ & $\begin{array}{l}\mathrm{F}_{2} \mathrm{I}_{4}\left(4 \mid \mathrm{m}^{-2}\right. \\
\text { daily) }\end{array}$ & 37.2 & 36.6 & 32.0 & 29.5 \\
\hline $\mathrm{T}_{5}$ & $\begin{array}{l}\mathrm{F}_{3} \mathrm{I}_{2}\left(21 \mathrm{~m}^{-2}\right. \\
\text { daily) }\end{array}$ & 28.8 & 27.1 & 23.6 & 20.8 \\
\hline$T_{6}$ & $\begin{array}{l}\mathrm{F}_{3} \mathrm{I}_{4}\left(4 \mid \mathrm{m}^{-2}\right. \\
\text { daily })\end{array}$ & 29.4 & 26.3 & 24.2 & 20.1 \\
\hline $\mathrm{T}_{7}$ & $\begin{array}{l}\mathrm{F}_{4} \mathrm{I}_{2}\left(2 \mid \mathrm{m}^{-2}\right. \\
\text { daily) }\end{array}$ & 35.1 & 33.6 & 30.0 & 27.3 \\
\hline $\mathrm{T}_{8}$ & $\begin{array}{l}\mathrm{F}_{4} \mathrm{I}_{4}\left(4 \mid \mathrm{m}^{-2}\right. \\
\text { daily) }\end{array}$ & 35.7 & 34.8 & 30.7 & 28.5 \\
\hline $\mathrm{T}_{9}$ & $\begin{array}{l}\mathrm{F}_{5} \mathrm{I}_{2}\left(2 \mid \mathrm{m}^{-2}\right. \\
\text { daily) }\end{array}$ & 34.6 & 33.0 & 29.4 & 26.7 \\
\hline $\mathrm{T}_{10}$ & $\begin{array}{l}\mathrm{F}_{5} \mathrm{I}_{4}\left(4 \mid \mathrm{m}^{-2}\right. \\
\text { daily) }\end{array}$ & 33.7 & 33.1 & 28.8 & 26.8 \\
\hline \multirow[t]{3}{*}{$\mathrm{T}_{11}$} & $\begin{array}{l}\text { FP (2। } \mathrm{m}^{-2} \\
\text { daily) }\end{array}$ & 26.8 & 25.0 & 22.1 & 18.9 \\
\hline & SEm \pm & 1.4 & 1.5 & 1.4 & 1.5 \\
\hline & $C D(p=0.05)$ & 4.0 & 4.3 & 4.2 & 4.4 \\
\hline
\end{tabular}

$25.0 \mathrm{mg} \mathrm{kg}^{-1}$ in $\mathrm{T}_{11}$ to 37.2 and $36.6 \mathrm{mg} \mathrm{kg}^{-1}$ in treatment $\mathrm{T}_{4}$ at $0-0.15$ and $0.15-0.30 \mathrm{~m}$ soil layer, respectively. The $\mathrm{NH}_{4}-\mathrm{N}$ content in the treatments $\left(\mathrm{T}_{4}\right.$ and $\left.\mathrm{T}_{3}\right)$ comprising with $\mathrm{I}_{2}$ and $\mathrm{I}_{4}$ were significantly superior to that recorded under farmers' practice $\mathrm{T}_{11}$ at both soil layer level. In general, $\mathrm{NH}_{4}-\mathrm{N}$ contents in farmers' practice were lower as compared to all the treatments at $0-0.15 \mathrm{~m}$ and $0.15-0.30 \mathrm{~m}$ depth. Farmers' practice was significantly inferior to rest of the treatments. As compared to the buffer plots, all the plots receiving chemical fertilizers along with organic source, bio-fertilizer and cow urine recorded higher ammonical- $\mathrm{N}$ content than the plots without organic and bio-fertilizers application. The increase in the FYM applied soil which enhances the decomposition of organic material and mineralization/ammonification of organic- $\mathrm{N}$ might have contributed $\mathrm{NH}_{4}-\mathrm{N}$ in soil. Due to chemical fertilizers application, increase in content is due to hydrolysis of nitrogenous fertilizers that resulted in the release of ammonium ions in soil. These results are in close conformity with the findings of Bhardwaj et al. (1994), Guldekar and Ingle 
(2009), Babita (2010), Singhal et al. (2012) and Subehia and Dhanika (2013).

\subsection{2. $\mathrm{NO}_{3}-\mathrm{N}$}

In table 2 presented data reveal that the nitrate- $\mathrm{N}$ content of soil differed significantly under different treatments. The range of variation was from 22.1 and $18.9 \mathrm{mg} \mathrm{kg}^{-1}$ under farmers' practice $T_{11}$ to 33.0 and $30.3 \mathrm{mg} \mathrm{kg}^{-1}$ under treatment $\mathrm{T}_{4}$ at $0-0.15 \mathrm{~m}$ and $0.15-0.30 \mathrm{~m}$, respectively. The treatment $\mathrm{T}_{4}$ increased the nitrate- $\mathrm{N}$ content numerically over all the treatments but statistically at par with treatments $T_{1}, T_{2}, T_{5}$, $\mathrm{T}_{6}$ and $\mathrm{T}_{11}$ at $0-0.15 \mathrm{~m}$ and $0.15-0.30 \mathrm{~m}$ depth. Application of fertilizers @ 100\% RDF through fertigation and basal both combined increased the $\mathrm{NO}_{3}-\mathrm{N}$ contents significantly higher overall the treatments. When different treatments were compared with initial value, $\mathrm{NO}_{3}-\mathrm{N}$ contents were found higher in all the treatments except farmers' practice $\left(T_{11}\right)$ in surface soil (0.0-0.15 $\mathrm{m}$ ) and subsurface soil $(0.15-0.30 \mathrm{~m})$. Increase in $\mathrm{NO}_{3}-\mathrm{N}$ content may be ascribed to the nitrification of $\mathrm{NH}_{4}-\mathrm{N}$ to $\mathrm{NO}_{3}-\mathrm{N}$ by soil microorganisms Prasad and Rokima, 1991; Santhy et al., 2001; Munoz et al., 2003; Babita, 2010.

\subsection{Urease activity}

\subsubsection{Surface soil}

The data presented in the Table 3 shows that organic source of nutrient with bio-fertilizers and cow urine application significantly affected the urease activity in surface soil with inorganic source of nutrients. Amongst all the treatments the highest urease activity $\left(22.1 \mathrm{\mu g} \mathrm{g}^{-1} \mathrm{~min}^{-1}\right)$ was recorded under the treatment where $100 \% \operatorname{RDF}(1 / 3 \mathrm{~N}$, full $\mathrm{P} \& \mathrm{~K}$ as basal ) $2 / 3 \mathrm{~N}$ through fertigation+Azo+PSB+cow urine were applied along with $2 \mathrm{It} \mathrm{m}^{-2}$ daily irrigation level. This might be due to the fact that better soil biological and physical condition due to the addition of organic nutrients, cow urine increased the continuity of conversion of nutrients from organic to inorganic form because it increases urease activity by urease enzyme; it acts on $\mathrm{C}-\mathrm{N}$ bonds other than peptide bonds in linear amides. However, lowest urease activity was recorded under treatment where farmers' practices were followed. When compared to initial status, all the treatments gave numerically higher urease activity. It was increased in all the treatments from the initial status on surface soil samples.

\subsubsection{Subsurface soil}

A perusal of the data presented in the table 3 shows that the effect of fertigation and organic nutrient source significantly affected the urease activity in subsurface soil in all the treatments. The highest urease activity was recorded in the treatment $\mathrm{T}_{3} ; 100 \% \mathrm{RDF}(1 / 4 \mathrm{~N}, \mathrm{P}$ and $\mathrm{K}$ as basal) 3/4N through fertigation+Azo+PSB+cow urine 2 It m ${ }^{-2}$ daily irrigation level. This might be due to conversion of nutrients from organic to inorganic form because it acts on $\mathrm{C}-\mathrm{N}$ bonds other than peptide bonds in linear amides and thus belong to a group of enzymes that include glutominase and amidase. Whereas, the lowest urease activity was recorded under treatment where
Table 3: Effect of drip irrigation and fertigation on urease activity ( $\left.\mu \mathrm{g} \mathrm{g}^{-1} \mathrm{~min}^{-1}\right)$, phosphatase activity $\left(\mu \mathrm{g} \mathrm{g}^{-1} \mathrm{hr}^{-1}\right.$ ) and biomass carbon $\left(\mu \mathrm{g} \mathrm{g}^{-1}\right)$

\begin{tabular}{|c|c|c|c|c|c|c|}
\hline \multirow[t]{3}{*}{$\begin{array}{l}\text { Treat- } \\
\text { ments }\end{array}$} & \multicolumn{2}{|c|}{$\begin{array}{l}\text { Urease activity } \\
\left(\mu \mathrm{g} \mathrm{g}^{-1} \mathrm{~min}^{-1}\right)\end{array}$} & \multicolumn{2}{|c|}{$\begin{array}{c}\text { Phosphatase } \\
\text { activity ( } \mu \mathrm{g} \mathrm{g}^{-1} \\
\left.\mathrm{hr}^{-1}\right)\end{array}$} & \multicolumn{2}{|c|}{$\begin{array}{c}\text { Biomass car- } \\
\text { bon } \\
\left(\mu \mathrm{g} \mathrm{g}^{-1}\right)\end{array}$} \\
\hline & \multicolumn{6}{|c|}{ Depth $(\mathrm{m})$} \\
\hline & $0-0.15$ & $\begin{array}{l}0.15- \\
0.30\end{array}$ & $0-0.15$ & $\begin{array}{l}0.15- \\
0.30\end{array}$ & $\begin{array}{c}0- \\
0.15\end{array}$ & $\begin{array}{l}0.15- \\
0.30\end{array}$ \\
\hline $\mathrm{T}_{1}$ & 18.0 & 16.0 & 4.71 & 3.67 & 74.63 & 67.9 \\
\hline $\mathrm{T}_{2}$ & 16.5 & 13.7 & 3.81 & 2.87 & 71.74 & 64.5 \\
\hline $\mathrm{T}_{3}$ & 22.1 & 17.3 & 6.03 & 4.95 & 81.77 & 76.1 \\
\hline $\mathrm{T}_{4}$ & 20.9 & 17.0 & 5.53 & 4.48 & 81.40 & 74.7 \\
\hline $\mathrm{T}_{5}$ & 14.9 & 13.0 & 3.83 & 3.30 & 69.37 & 64.4 \\
\hline $\mathrm{T}_{6}$ & 17.7 & 14.9 & 3.73 & 2.63 & 67.67 & 61.9 \\
\hline $\mathrm{T}_{7}$ & 20.5 & 17.2 & 5.07 & 4.23 & 78.00 & 71.4 \\
\hline $\mathrm{T}_{8}$ & 19.5 & 16.8 & 4.58 & 3.48 & 75.95 & 69.0 \\
\hline $\mathrm{T}_{9}$ & 12.9 & 11.1 & 3.72 & 2.36 & 52.05 & 51.2 \\
\hline $\mathrm{T}_{10}$ & 11.8 & 10.7 & 3.65 & 2.30 & 53.84 & 49.6 \\
\hline $\mathrm{T}_{11}$ & 11.5 & 10.6 & 3.53 & 2.48 & 65.33 & 59.7 \\
\hline SEm \pm & 0.6 & 0.5 & 0.3 & 0.3 & 0.8 & 1.0 \\
\hline $\begin{array}{l}\text { CD } \\
(p=0.05)\end{array}$ & 1.7 & 1.5 & 0.9 & 0.9 & 2.2 & 3.0 \\
\hline Initial & 10.3 & 9.2 & 3.61 & 2.30 & 50.2 & 48.2 \\
\hline
\end{tabular}

farmers' practices was followed.

When compared to initial status, all the treatments gave numerically higher urease activity. In general, in both surface and subsurface soil samples increased the urease activity of soil with increasing soil water content. Similar results were reported by Jaun et al. (2008).

\subsection{Phosphatase activity}

\subsubsection{Surface soil}

The data presented in the table 3 shows that organic source of nutrient, bio-fertilizers and cow urine application significantly affected the phosphatase activity in surface soil. Amongst all the treatment combinations the highest phosphatase activity was recorded under the treatment where $100 \% \operatorname{RDF}(1 / 3 \mathrm{~N}$, full $P$ \& $K$ as basal) $2 / 3 \mathrm{~N}$ through fertigation+Azo+PSB+cow urine were applied along with $2 \mathrm{I} \mathrm{m}^{-2}$ daily irrigation level. This might be due to the fact that better soil physical condition due to organic manure, application of phosphorus solubilizing bacteria which increase the phosphatase activity and addition of bio-fertililizers increased mineralization of nutrients. The supply and availability of additional mineralizable and readily hydrolysable carbon is responsible for higher microbial activity and microbial population. However, lowest (3.53 $\mu \mathrm{g} \mathrm{g}^{-1}$ soil) phosphatase activity was recorded under farmers' practice. 
When compared to initial status, all the treatments gave numerically higher phosphatase activity except farmers' practice. It was increased in all the treatments from the initial status on surface soil samples. Similar results were reported by Bedi et al. (2009); Rai and Yadav (2011); Nath et al. (2012).

\subsubsection{Subsurface soil}

The data presented in the table 3 shows that similarly results also found in subsurface soil.

\subsection{Biomass carbon}

\subsubsection{Surface soil}

The result shows that organic source of nutrients and biofertilizers significantly affected the biomass carbon in surface soil (Table 3). Amongst all the treatments the highest ( 81.77 $\mu \mathrm{g} \mathrm{g}^{-1}$ soil) biomass carbon was recorded under the treatment $\mathrm{T}_{4}$ where $100 \% \operatorname{RDF}(1 / 3 \mathrm{~N}$, full P\&K as basal) $2 / 3 \mathrm{~N}$ through fertigation+Azo+PSB+cow urine were applied along with $21 \mathrm{~m}^{-2}$ daily irrigation level. This might be due to the fact that better soil physical condition due to better availability of nutrients and more addition of bio-fertililizers and cow urine increased mineralization of nutrients. The supply and availability of additional mineralizable and readily hydrolysable carbon is responsible for higher microbial activity and microbial biomass carbon. However, the lowest ( $52.05 \mu \mathrm{g} \mathrm{g}^{-1}$ soil) biomass carbon was recorded under treatment $\mathrm{T}_{9}$.

The treatments $\mathrm{T}_{3}(100 \%$ RDF (1/3N, full P\&K as basal) $2 / 3 \mathrm{~N}$ through fertigation+Azo+PSB+cow urine with $21 \mathrm{~m}^{-2}$ daily irrigation level) was found statistically at par with treatment $\mathrm{T}_{4}$ (100\% RDF (1/3N, full P\&K as basal) $2 / 3 \mathrm{~N}$ through fertigation+ Azo+ PSB +cow urine with 4 It $\mathrm{m}^{-2}$ daily irrigation level) and significantly different with all other treatments.

The use of bio-fertilizer, FYM and cow urine recorded significantly higher biomass carbon as compared to only $100 \%$ RDF through fertigation. This might be due to the fact that readily available carbon fraction of compost supported the development of microbial population and proper moisture level increase soil microbial carbon biomass. The basal application of fertilizers also increases availability of nutrient and carbon biomass and similar result reported by Datt et al. (2013).

When compared to initial status, all the treatments gave significantly higher biomass carbon. The biomass carbon increased from its initial value in all the sources of nutrients applied. The application of organic source of nutrients, make soil micro flora and fauna more active that resulted in an increase in the biomass carbon. Similar results were also reported by Kukreja et al. (1991) and Ghoshal and Singh (1995).

\subsubsection{Subsurface soil}

The data presented in the table 3 shows that organic nutrient source and bio-fertilizers significantly affected the biomass carbon in subsurface soil and followed similar trend as surface soil. Similar results were also reported by Selvi et al. (2004), Gogoi et al. (2010); Nath et al. (2012).

\section{Conclusion}

Treatment $\mathrm{T}_{4}$ revealed higher inorganic $\mathrm{N}$ forms and biological properties of soil compared to other treatments. While comparing the treatments, it is found that cow urine at $5 \%$ concentration resulted in higher urease activity. The application of organic source of nutrients, make soil micro flora and fauna more active that result in an increase of the biomass carbon. While comparing the treatments, it is found that treatments with PSB addition resulted in higher phosphatase activity than the treatments without PSB addition.

\section{References}

Babita, 2010. Nitrogen dynamics in soil plant system as influenced by long-term use of chemical fertilizers and amendments in an aid Alfisol. M.Sc. Thesis, Department of Soil Science, CSK Himachal Pradesh Krishi Vishvavidyalaya, Palampur, India.

Bedi, P., Dubey, Y.P., Datt, N., 2009. Microbial properties under rice-wheat cropping sequence in an acid Alfisol. Journal of the Indian Society of Soil Science 57, 373-377.

Bhardwaj, V., Bansal, S.K., Maheshwari, S.C., Omanwar, P.K., 1994. Long-term effects of continuous rotational cropping and fertilization on crop yields and soil properties-III. Changes in the fractions of N, P and $\mathrm{K}$ of the soil. Journal of the Indian Society of Soil Science 42, 392-397.

Black, C.A., 1965. Methods of soil analysis part-I, American Society of Agronomy, Madison, Wisconsin, USA.

Chen, Y.P., Rekha, P.D., Arunshen, A.B., Lai, W.A., Young, C.C., 2006. Phosphate solubilizing bacteria from subtropical soil and their tricalcium phosphate solubilizing abilities. Applied Soil Ecology 34, 33-41.

Church, D.C., 1976. Digestive Physiology and Nutrition of Ruminants. $2^{\text {nd }}$ ed. D.C.Church/O \& B Books, Corvallis, OR.

Datt, N., Dubey, Y.P., Chaudhary, R., 2013. Studies on impact of organic, inorganic and integrated use of nutrients on symbiotic parameters, yield and quality of Frenchbean (Phaseolus vulgaris L.) vis-a-vis soil properties of an acid alfisol. African Journal of Agricultural Research 8, 2645-2654.

Ghoshal, N., Singh, K.P., 1995. Effects of farm yard manure and inorganic fertilizer on the dynamics of soil microbial biomass in a tropical dry land agro ecosystem. Biology and Fertility of Soils 19, 231-238.

Gogoi, B., Barua, N.G., Baruah, T.C., 2010. Effect of integrated supply of nutrients on soil microbial biomass carbon in an Inceptisol of Assam. Journal of the Indian Society of Soil Science 58, 241-244.

Guldekar, V.D., Ingle, S.N., 2009. Dynamics of nitrogen forms 
in soil under long-term fertilization to sorghum-wheat sequence in vertisols. Punjabrao Krishi Vidyapeeth Research Journal 33, 21-24.

Imamsaheb, S.J., Hanchinmani, C.N., Ravinaik, K., 2014. Impact of drip irrigation and fertigation on growth, yield, quality and economic returns in different vegetable crops. Asian Journal of Horticulture 9(2), 484-491.

Jackson, M.L., 1973. Soil Chemical Analysis. Prentice hall inc, Englewood cliffs, New Jersey, USA.

Jaun, L., Bingqiang, Z., Xiuying, L., Ruibo, J., Hwatbing, S., 2008. Effects of long-term combined application of organic and mineral fertilizers on microbial biomass, soil enzyme activities and soil fertility. Agricultural Sciences in China 7, 336-343.

Jensen, M.H., 2002. Controlled environment agriculture in deserts tropics and temperate regions-A world review. Acta Horticulturae 578, 19-25.

Kukreja, K., Mishra, M.M., Dhankar, S.S., Kapoor, K.K., Gupta, A.P., 1991. Effect of long-term manurial application on microbial biomass. Journal of the Indian Society of Soil Science 39, 685-688.

Liesack, W., Janssen, P.H., Rainey, F.A., Ward-Rainey, N.L., Stackebrandt, E., 1997. Microbial diversity in soil: The need for a combined approach using molecular and cultivation techniques, In: van Elsas, J.D. (Eds.), Modern Soil Microbiology. Marcel Dekker Inc., New York, 375-439.

Lovell, R.D., Jarvis, S.C., 1996. Effects of urine on soil microbial biomass, methanogenesis, nitrification and denitrification in grassland soils. Plant and Soil 186, 265-273.

Monisha, R., Maurya, S.K., Singh, P.K., Maurya, R., 2014. Screening of improved cultivars of cucumber in naturally ventilated polyhouse under tarai condition of Uttarakhand. Journal of Hill Agriculture 5(1), 72-75.

Munoz, G.R., Powell, J.M., Kelling, K.A., 2003. Nitrogen budget and soil nitrogen dynamics after multiple applications of unlabelled or ${ }^{15} \mathrm{~N}$ enriched dairy manure. Soil Science Society of America Journal 67, 817-825.

Nath, D.J., Ozah, B., Baruah, R., Barooah, R.C., Borah, D.K., Gupta, M., 2012. Soil enzymes and microbial biomass carbon under rice-toria sequence as influenced by nutrient management. Journal of the Indian Society of Soil Science 60, 20-24.

Nico, M., Ribaudo, C.M., Gori, J.I., Cantore, L.M., Cura, J.A., 2012. Uptake of phosphate and promotion of vegetative growth in glucose-exuding rice plants (Oryza sativa) 6 inoculated with plant growth-promoting bacteria. Applied Soil Ecology 61, 190-195.

Piper, C.S., 1950. Soil and plant analysis. Inter Science Publication Inc, New York, 105, 247-255.
Prasad, B., Rokima, J., 1991. Integrated nutrient management (1) Transformation of applied $\mathrm{N}$ into various $\mathrm{N}$ fractions in relation to its availablility and uptake in calcareous soils. Journal of the Indian Society of Soil Science 39, 712-716.

Rai, T.N., Yadav, J., 2011. Influence of inorganic and organic nutrient sources on soil enzyme activities. Journal of the Indian Society of Soil Science 59, 54-59.

Reddy, T.Y., Reddy, G.H.S., 2003. Principles of Agronomy. Kalyani Publication, New Delhi, 319-320.

Santhy, P., Muthuvel, P., Selvi, D., 2001. Nitrogen fractions: status and impact on yield, uptake and available nitrogen in long term fertilizer experiment. Madras Agricultural Journal 88, 26-31.

Sathya, S., Pitchai, G. J., Indirani, R., Kannathasan, M., 2008. Effect of fertigation on availability of nutrients (N, P \& K) in soil-a review. Agricultural Reviews 29(3), 214-219.

Selvi, D., Santhy, P., Dhakshinamoorthy, M., Maheshwari, M., 2004. Microbial population and biomass in rhizosphere as influenced by continuous intensive cultivation and fertilization in an Inceptisol. Journal of the Indian Society of Soil Science 52, 254-257.

Singh, R.A., 1980. Soil Physical Analysis. Kalyani Publishers, Ludhiana, India.

Singhal, S.K., Singh, R.D., Sharma, V.K., Sharma, S.K., 2012. Impact of integrated use of fertilizer and enriched compost on yield, nitrogen uptake by wheat and frations of soil nitrogen in semi-arid condition. Indian Journal of Agricultural Research 46, 262-268.

Solaimalai, A., Baskar, M., Sadasakthi, A., Subburamu, K., 2005. Fertigation in high value crops. Agricultural Reviews 26(1), 1-13.

Subehia, S.K., Dhanika., 2013. Soil nitrogen fractions and its effect on rice (Oryza sativa) yield under integrated nutrient management in a north-western Himalayan soil. Indian Journal of Soil Conservation 41, 47-51.

Tabatabai, M.A., Bremner, J.M., 1969. Use of p-nitrophenyl phosphatase for assay of soil phosphatase activity. Soil Biology and Biochemistry 1, 301-307.

Tabatabai, M.A., Bremner, J.M., 1972. Assay of urease activity in soils. Soil Biology and Biochemistry 4, 479-489.

Torsvik, V., Goksoyr, J., Daae, F.L., 1990. High diversity in DNA of soil bacteria. Applied and Environmental Microbiology 56, 782-787.

Torsvik, V., Ovreas, L., 2002. Microbial diversity and function in soil: from genes to ecosystems. Current Opinion in Microbiology 5, 240-245.

Vance, E.D., Brookes, P.C., Jenkinson, D.S., 1987. An extraction method for measuring soil microbial biomass carbon. Soil Biology and Biochemistry 19, 703-707. 